\title{
The making and breaking of states: the end of empire in India revisited
}

\author{
Raleigh Lecture on History \\ read 27 November 2012 by
}

\section{JUDITH M. BROWN}

Abstract: Recent events in the Arab world have sharpened and widened public interest in the way states can be broken and made. Since the end of the Second World War the world has seen three great waves of state-breaking and state-making: the end of European empires; the collapse of the Soviet Union; and the contemporary 'Arab Spring'. By revisiting an example from the first of these great waves, perhaps the greatest 'imperial ending' - the end of British imperial rule in India in 1947, this lecture investigates issues which may prove instructive in probing the dynamics of other phases of turbulence in the structures and nature of states. It addresses four major questions which are relevant across the many different episodes of state breaking and making, with the help of evidence from the case of the South Asian subcontinent. What is the relationship between state and society and the patterns of relationship which help to determine the nature and vulnerability of the state? What makes a viable and destabilising opposition to the imperial state? What is the nature of the breaking or collapse of that state? How are states refashioned out of the inheritance of the previous regime and the breaking process?

Key words: British Raj, civil resistance, decolonisation, Gandhi, imperialism, India, nationalism, non-violence, Pakistan, World War

Lord Wavell, the penultimate Viceroy of India, kept a personal journal, marked by devastating honesty and no little sense of humour. On the last night of 1946 he wrote, 'while the British are still legally and morally responsible for what happens in India, we have lost nearly all power to control events; we are simply running on the momentum of our previous prestige'. ${ }^{1}$ Seven and a half months later the British empire in India had ended; and Nehru, as independent India's first prime minister, made his

\footnotetext{
${ }^{1}$ Moon (ed). (1973: 402).
} 
famous 'Tryst with Destiny' speech, as midnight indicated the start of independence day on 15 August $1947 .{ }^{2}$ The extraordinarily rich documentation produced by the British imperial state and by Indian political actors enables us to examine the dynamics of this 'imperial ending' and the emergence of two successor states on the South Asian subcontinent. But my intention is that in probing the end of empire in India we can see underlying issues of wide interest, not just to those who are specialists on South Asia. Since the Second World War our world has experienced three great waves of state breaking and state making: the end of the European empires, the collapse of the Soviet Union and its network of eastern European states, and the contemporary 'Arab Spring'. By revisiting the greatest of those first imperial endings, we can ask whether there are themes and patterns which prove useful in understanding the dynamics of other phases of turbulence in the structures and nature of states.

But first a word of caution: what do we mean by breaking and making states? I shall return to this, but lurking behind these terms is the question whether we are talking about regime change - a change in the holders of power and their modes of operation - or whether we mean something much more radical, involving the reconstitution of state structures on a different ideological and socio-economic basis, a shift in the relationship between state and society, and transformation of the structures of decision-making and administration.

First, let me offer a route map of how I propose to organise my enquiry. I shall examine four broad and crucial questions, applicable to any instance of state breaking and making, and try to answer them from the evidence out of India. What is the relationship between the state and society and how does this help us to understand the nature of the state, its strength and its vulnerability? What makes a successful opposition to an established state? What is the nature of the breaking of a particular state? Then finally how are states remade, and how do those who come after use what they inherit from the previous regime and the breaking process?

\section{STATE AND SOCIETY}

Contemporary reporting of the Arab Spring has doubtless had many deficiencies: but of one thing they have made us all particularly aware - the crucial nature of the societies of the Arab world, their internal ethnic divisions, the significance of large cities and their predominantly young populations of the well educated but unemployed and disaffected. Managing the political and administrative affairs of such turbulent, divided societies is a state project very different from the more remote state

\footnotetext{
${ }^{2}$ Gopal (ed.) (1985: 135-6).
} 
presence in older, more stable agricultural societies with recognised hierarchies and settled communities which largely run their own affairs. But even in such simpler, stable societies there can be flashpoints of distress which can profoundly challenge the state if generalised and given a legitimising ideology of protest. The rise of almost instant news reporting and electronic communication makes any contemporary political challenge or crisis instantly national and international in a way impossible to comprehend even two to three generations ago when the written and spoken word, and possibly the radio and telephone, were the most rapid means of spreading public knowledge. It is obvious why historians have become so interested in the nature and dynamics of rumour as a mode of communication in societies marked by illiteracy and limited means of communication.

Just as important is the nature of the state itself and its relation to the social order; in particular whether it is in the hands of those considered legitimate rulers by the majority, whether it is the preserve of local, accepted elite groups, or whether it is, as in the case of India, an imperial state driven by external personnel and the needs of a foreign power. In the case of an imperial state there is an important difference between a settler state, where they are expatriates who build a personal stake in the land and economy of the colony, and have consequent leverage over the state; and an imperial state with limited foreign personnel to manage its civil operations and provide its military and police functions. The historian concerned with state stability and instability also has to investigate the multiple roots and buttresses of state power, which range from those that operate in the sphere of minds and hearts, generating legitimacy, to the more prosaic but essential ones, such as regular recruitment of trustworthy state officials, the financial capacity to pay them adequately and regularly, and to attract unpaid but significant social and political support, particularly from those who in turn can deliver the loyalty of those to whom they are leaders and patrons. Throughout the history of organised states the backing or at least acquiescence of foreign powers is also an element in the equation of state power. (You have only to read some of the obscurer books of the Old Testament to see what happened to small, nascent states which played an early form of international politics against the great Middle Eastern empires of the day.) The contemporary counterparts of similar patterns of foreign pressure and intervention have regularly appeared on our television screens as the international community has debated sanctions, no-fly zones, and recognition of governments in waiting.

So I turn now to the case of the British imperial state in India and examine its nature and its relationship to society on the subcontinent. At the beginning of the 20th century Britain's imperial state consisted of two thirds of what is now India, Pakistan and Bangladesh. The remaining third was in the control of diverse types of Indian princely families who acted as its subsidiary allies. The area under direct British 
control was still largely rural and home to established agricultural communities with their own hierarchies of power. There were significant trading groups who managed vibrant internal and international networks of trade - ranging from the small dealers in essential domestic commodities to those whose connections depended on the Indian Ocean and spread out to Africa in the west and south-east Asia to the east. Older urban centres which had grown up as centres of administration, internal commercial hubs and places of religious observance were being joined by new cities built on trade and increasingly manufacturing. But the imperial state's main concern was still rural stability, keeping the countryside loyal and collecting revenue from the proceeds of land and agriculture. High death rates, particularly among children and young mothers, helped to depress population growth; and unlike many contemporary developing societies there was no demographic density in the young adult age group. The degree to which Indian people as a whole could perceive of themselves as a political unity was also limited, as was their capacity for continent-wide organisation - by geography, poor communications, the fact that there were eleven or more major languages on the subcontinent, and consequently by significant regional identities which had deep historical roots. Illiteracy, too, was a barrier to any identity other than the local. By 1921 only 14.4 per cent of males over the age of 5 in British India were literate, while the figure for girls and women was just 2 per cent. ${ }^{3}$ Religious differences also contributed to the development of distinctive local societies and senses of community.

The British imperial state was in a very real sense hardly British at all — despite the British talent for imperial pageantry and the fact that ultimate authority over the subcontinent lay with the British Parliament. There were virtually no British settlers in India, and the number of expatriates, including women and children, was tiny. The 1921 Census indicated a population which had nearly reached 320 millions on the subcontinent. Of these 247 millions were enumerated in British India. The European population in British India consisted of just under 157,000, of whom 45,000 were women. The vast majority of the European men were in civilian government service, or were officers in the Indian army or were officers and men in the regiments of the British army serving in India. ${ }^{4}$ To govern India the British had constructed a very light framework of government, with its key expatriate representative being the District Officer. But essentially the imperial state was founded on a network of alliances with different Indian groups who had influence in their own economic and social worlds. Their allies ranged from great landlords, where these existed, to representatives of dominant urban and rural groups who could deliver the loyalty of those for whom they were patrons and masters. These networks were rarely articulated. But to those

${ }^{3}$ Indian Statutory Commission Volume 1. Report of the Indian Statutory Commission Volume 1-Survey CMD 3568 (1930: 382).

${ }^{4}$ Ibid. (12, 46-7). 
present at the time, and to historians, it was and is quite clear who was trusted and used and rewarded: for example those local notables who had access to the District Officer in each locality, whose honour and influence was consequently affirmed while being used by the imperial state; or those who were nominated from each Province for honours at the sovereign's birthday and at new year, as a reward for their loyalty and 'public service'. ${ }^{5}$ By the early 20th century the British were diversifying their range of Indian allies, particularly to include those who were becoming more influential, and often very wealthy, through access to English language education and modern professions such as Law. ${ }^{6}$ They experimented with giving them, as well as their established friends, more formal places and roles in decision-making and consultation through a series of constitutional reforms. From 1919 in particular, after the MontaguChelmsford Reforms, those Indians who were prepared to stand for election to expanded and empowered provincial and central legislatures, gained access to significant and legitimate influence within the imperial state. Beyond alliances with influential Indians the British imperial state also relied totally on the huge numbers of Indians who were actually on its payroll - those who carried on the work of civil government, beneath the District Officer, in innumerable hot and dusty offices where land registration documents and tax records piled up, those who enabled the court system to function, and those who joined the ranks of the police and the Indian army. For most Indians it was an Indian face which was the face of the raj.

States, of course, also depend on that more elusive foundation, legitimacy. One could argue that legitimacy is more important in the long run than a grip on organised force. Certainly the British imperial state did not have the physical power to control India in any simple sense. Its troops were too few in number, and its police inherently unreliable. It relied heavily on the fact that although it could deploy force menacingly in particular and localised situations, and although it did not hesitate to lock up or execute those considered a danger to the state, it needed the acquiescence of the vast majority of Indians if it was to survive. The infamous massacre of over 300 unarmed people in the enclosed space of Jallianwalla Bagh in 1919, during a phase of deep civil

${ }^{5}$ For evidence of networks of support in different rural areas see Reeves (1991), particularly chaps 1 \& 2; Ansari (1992), particularly chap. 2. An excellent description of the imperial state at work in one particular province is Part 2 of Kudaisya (2006).

There is no published study of how the honours system worked in India but the papers of various governors of provinces, held in the India Office collections, provide fascinating evidence of their political use.

${ }^{6}$ A good example of this trend was Motilal Nehru (1861-1931), father of Jawaharlal Nehru, India's first prime minister after independence. Although he was not from a landed or influential family he became a successful and very wealthy lawyer in the United Provinces. His status in relation to the imperial state was evident from the fact that he became a friend and drinking companion of the provincial governor, Sir Harcourt Butler, and was personally invited to the 1911 royal durbar in Delhi. 
unrest in Punjab province, underlined for the British that increasingly the display of brute force was counter-productive. The officer who gave the order to shoot was dismissed from the service. The records of internal discussions within the highest ranks of the raj on how to treat Gandhi as he challenged British rule from the 1920s also demonstrate just how sensitive the British were to the legitimacy as well as the legality of their actions as state actors.

Assessing and understanding the legitimacy accorded to the British imperial state until around the 1930s is difficult. We can probably say that the majority of Indians would have been content with any state which did not over-tax and did not interfere with the daily life of its subjects. Certainly the British worked on this assumption and were always deeply sensitive to tax levels, particularly the land revenue which touched all rural communities. Moreover, they took care not to interfere in sensitive areas of private, religious and community life. A torrent of opposition to their attempt in 1891 to raise the age of consent from 10 to 12 warned them off the territory of sexuality and family identity and power. At a more sophisticated level of political thinking most Indians accepted, however reluctantly, that the imperial state was a fixture in their lives, and that there could be no harking back to earlier types of Indian state if they wished to avail themselves of the benefits of new forms of education, new careers, and access to the world economy. Even when the ideas of a united and legitimate Indian nation and of Home Rule became normal currency among the overtly political from the time of the Great War onwards, there were few who sought to overthrow the imperial state: their hope was to reform it or to inherit it. Gandhi was one of the few who challenged the whole idea of the imperial state in his 1909 pamphlet, Hind Swaraj ('Indian Home Rule'): for him it was a moral outrage. But he was only too aware just how deep the roots of British rule had struck in Indian society and in Indian minds. As he wrote to his imagined interlocutor, 'The English have not taken India; we have given it to them. They are not in India because of their strength, but because we keep them. ${ }^{97}$ Of course legitimacy has an international as well as a national or internal dimension. World opinion and the distribution of international power meant that there was no serious international challenge to the British position in India until the Second World War. The ideology of Communism was certainly a constant worry to the British in India, as a variant on their older fears of a Russian presence on their northern Indian border. But in truth there was little substance in these fears. At home even the presence of the new Labour Party did not break up the unanimity within the political class of support for the empire and Britain's main imperial state. Opposition to the empire (in essence rather than in practice) was the preserve of a few. Moreover, Britain's major allies in the western world had no material or ideological reason to challenge her rule in India.

${ }^{7}$ Parel (ed.) (1997: 39). 
Just before the Great War Lord Hardinge, Viceroy of India, judged that British rule was solid and immoveable in the foreseeable future. In his words, any idea of India evolving towards some form of colonial self-government was 'ridiculous and absurd' ${ }^{8}$ But the British imperial state was profoundly vulnerable. Hardinge himself was admitting this privately within months of the outbreak of the Great War. His main worry in late 1914 was the way the number of British troops in India had been greatly reduced. ${ }^{9}$ However, military power played only a small part in securing the state. At a far deeper level the state was vulnerable to the erosion of its legitimacy, if for example it was challenged by a serious nationalist ideology, particularly if this drew strength from deeply felt discontents. It would be stretched if it were confronted by new unities in Indian society and politics. It could be fatally weakened if it lost critical numbers of its paid and unpaid Indian allies. It was also vulnerable to external political and financial shocks, such as a global recession, world war, and shifting global ideologies which might erode its support in Britain and among its international allies. As we shall see, all these potential threats began to develop in the interwar period, culminating in the 1940s.

\section{SUCCESSFUL OPPOSITION MOVEMENTS}

For the moment let us turn to the issue of what might make a successful opposition movement to the state, drawing our evidence from India. As we know from experience of state opponents in China, Iran, Russia and Syria, to name only a few, opposition is a dangerous and often unsuccessful business.

The Indian evidence suggests that the key to a movement's success in opposing the state is its ability to probe that state's particular weaknesses; to challenge and undermine it just where it is most vulnerable. Not all states have the same vulnerabilities, so successful opposition will also vary. In the Indian case there were, arguably, four main characteristics of the opposition movement which, from 1920, challenged the British raj and gave it leverage in that context against that particular state. It was organised and orchestrated by the Indian National Congress, under Gandhi's leadership though not always under his control.

\footnotetext{
${ }^{8}$ Hardinge to Lord Sanderson, 25 July 1912, Hardinge MSS (92), Cambridge University Library.

${ }^{9}$ Hardinge to Sir Valentine Chirol, 19 Nov. 1914, Hardinge MSS (93).
} 


\section{Ideology}

Congress developed an ideology which challenged British legitimacy as rulers, and inculcated among many Indians the intoxicating sense that change was actually possible. ${ }^{10}$ At its most sophisticated this was an ideology of nationalism and the validity of the claims of nation states to govern themselves, which had received international backing in the Great War. Consequently much time and effort was expended by political leaders on discussion about the nature of the Indian nation. But Congress never had a single or simple ideological stance. This was one of its strengths. Different groups could pour into its general claims for freedom content from their own beliefs and hopes. Even at the leadership level the ideological discourse was open and porous. Gandhi, for example, spoke in terms of morality and the need to build the nation from the roots upwards by dealing with social and economic issues. ${ }^{11}$ Jawaharlal Nehru, on the left of the ideological spectrum, spoke of radical economic change and greater equality. ${ }^{12}$ At a lower level of leadership vernacular speakers expounded a new national future in terms their hearers could understand and with which they could identify in their specific local situations. This eventually destabilised popular acceptance of British rule, or at least acquiescence in it, and threatened the standing of those who allied themselves with the ruling power as paid or unpaid allies. Few could hope for political standing and influence in India itself unless they subscribed to the ideology of nationalism and called for fundamental political change. In the longer run it also established Gandhi and Congress as the authentic voice of India in the wider world, thus destabilising the legitimacy of British rule in an international context. It is no surprise that when the British in 1942 eventually offered independence after the Second World War, the trigger for this move was pressure from their key American allies.

\section{Nature of national movements of opposition}

But ideology was not enough, however welcoming that ideology to different emphases and interpretations. What gave Indian nationalism its breadth and strength was its ability to absorb so many different and often local desires and discontents. This was its second great characteristic. Leaders of local protest movements were able to make fruitful alliances with the national movement of opposition to the imperial state. They gained credibility and organisational assistance, while their causes and their supporters gave the national movement continental spread and genuine substance. The peasant

\footnotetext{
${ }^{10}$ See the memories of Jawaharlal Nehru in his autobiography (1936: 76-7).

${ }^{11}$ See Brown (ed.) (2008), particularly Part IV, entitled 'India Under British Rule: Making a New Nation'.

${ }^{12}$ See Nehru (1936); also Brown (2003).
} 
movements originating in economic distress after the Great War and during the Depression were the most obvious case. But in cities, too, for many reasons, different groups found a voice in Congress and a mode of exerting pressure on the state. The mechanism for this incorporation was at times the very constitutional reform the British had launched in an attempt to expand their range of allies. Those elected to the reformed legislatures often brought with them new grievances and demands, and in voicing them gained more credibility as local politicians; while their new status gave them access to the British, and so earned them repute as local fixers of real problems and people who could give access to desirable resources. But during those times when Congress launched campaigns of non-cooperation with the raj, local protests were incorporated into these campaigns because provincial leaderships were given great leeway in their local objectives and styles of action. Civil resistance was an arena in which the reality of the nation was demonstrated: it was also a crucial mechanism for binding together multiple protests and oppositions. ${ }^{13}$

\section{Organisation and communication}

This leads us to consider the issue of organisation and communication. This is critical for any opposition. From the perspective of a new century it is hard but essential to remember the limitations on public communication in India in the first half of the 20th century - mass illiteracy, significant language barriers, slow travel: and of course none of the electronic modes of instant communication which have helped contemporary opposition movements. Congress was the one political party with a genuinely national organisation after Gandhi had helped to restructure it in 1920. On paper at least it stretched from the national Working Committee and annual meeting down to village level. It was through this network that programmes were organised and messages were sent-by post, the telegraph system, and by leaders' tours. The vibrant political press helped the process of political communication and education. But vital to the mechanics of communication and organisation was Gandhi and his supporting entourage. Gandhi lived in the ashram communities which he made his home the simple moral life he preached as the foundation of a free nation; as he said in 1945, 'My life is its own message. ${ }^{14} \mathrm{He}$ also spent much of his time on the move, addressing huge crowds, speaking to groups of local leaders. He was at the heart of a travelling cavalcade which far surpassed anything previously experienced by Indians as a mode of political communication. When he had any leisure at home or travelling he was always

\footnotetext{
${ }^{13}$ For studies of Gandhi's major civil resistance movements in 1920-2 and 1930-4 see Brown (1972) and (1977).

${ }^{14}$ Interview reported in The Hindu, 15 June 1945, Brown (ed.) (2008: 8).
} 
writing - articles for his own two newspapers, religious discourses, and a number of key texts about his own life. (His writing is often excruciating to read, particularly when fatigue made him switch from his right hand to his left!) Gandhi's personality and undoubted charisma, his energy and creativity as a communicator, were crucial in helping to create and manage new forms of opposition to the raj, particularly if these confronted it with dangerous new unities, eroding at least some of the differences which as Gandhi recognised had allowed the British to rule India.

\section{Non-violence}

The most distinctive new form of opposition to the imperial state was of course non-violent resistance - the last of the characteristics of Indian opposition we must note. For Gandhi non-violence was a moral imperative. ${ }^{15}$ For most of the political class it was a pragmatic choice: ${ }^{16}$ they knew only too well that the British would deal ruthlessly with outbreaks of violence and with those who participated in them. But non-violence made life politically difficult for the British. They were confused about the best way to deal with thousands of Indians who declined to cooperate with their rule or broke the law with the intention of ending in prison. Their policing and prison resources were seriously stretched. And non-violence made good journalistic copy, attracting sympathy from many millions more Indians who never actively participated in opposition, and also from significant numbers of foreign observers who read in the international press about imperial police beating non-violent resisters, and locking up a serious-minded national leadership. Peaceful resistance was also essentially public and political theatre, demonstrating far more powerfully than words could describe that an Indian nation was on the march, that it could subvert the imperial state by withdrawing cooperation, and that vast numbers of Indians would no longer acquiesce in the state's authority. As we have seen, crucial foundations of the imperial state in India were a degree of legitimacy, popular acquiescence and also the active cooperation of many in the state enterprise. Gandhi had understood this very early in his career, and from 1920 he deliberately chose to lead non-cooperation with the state on issues which would undermine its legitimacy and encourage people to withdraw their cooperation. Opposition to the salt tax in 1931 for example was an issue intended to appeal to everyone who cooked or ate. Refusal to pay it would never fundamentally harm state finances, but it was an emotive issue and opposition threatened the legitimacy of the raj's tax system; as of course did various local campaigns of resistance to land revenue in times of hardship. Refusal to stand for election to the reformed

\footnotetext{
${ }^{15}$ For some of Gandhi's writings on non-violence see ibid., Part V.

${ }^{16}$ For example, see the discussion by J. Nehru on this issue in his autobiography (1936: chap. XII).
} 
provincial legislatures was an even more overt strategy of withdrawal of the sort of cooperation which made the state's political system function. Gandhi's strategies of non-violent resistance would clearly not have worked in the context of other states with different sources of power and different potential weaknesses. Indeed the evidence of state power and coercion in Nazi Germany, and its ruthless handling of its Jewish population, was a major challenge to Gandhi's commitment to non-violence in all circumstances, even in his own life time. However, the history of nationalist opposition to the British in India does indicate some of the characteristics which contribute to successful opposition movements.

\section{THE BREAKING OF THE IMPERIAL STATE}

Let us turn now to the breaking of the imperial state. This happened very rapidly in the months after the war ended as Lord Wavell noted in his journal in the final hours of 1946. However, the nationalist opposition movement had not of itself made British rule impossible. In 1937 a further round of constitutional reform and radical devolution of power to elected Indian politicians in the provinces had seemed to create a working system of alliances on which the imperial state had re-established itself. However, the impact of the war proved fatal to that system and to the raj. Threatened in Asia as well as Europe, the British bought the goodwill of their American allies with the offer of independence for India after the war. There could be no going back from that point in 1942. But longer term processes had also undermined the imperial state. Depression and war had weakened it financially. Many of those who once had been its political allies were less influential or had defected to the nationalist camp. Recruitment of Europeans to the elite Indian Civil Service had proved increasingly difficult since 1918, and by the end of the Second World War even that steel frame of the state was half Indian in personnel. Moreover the Muslim minority's fears for its future in India now that the British were clearly going had triggered a situation of corrosive political distrust and total failure among the politicians to agree on the nature of the new Indian state. Violence between Indians themselves in the name of religion threatened law and order in some places, had corrupted the police and it was feared might even pervade the army. In London the prime minister, Attlee, opposed Wavell's wish to have in place a so-called 'breakdown plan'. With great discourtesy Attlee ignored and then sacked the Viceroy. But even Attlee was quite clear by late 1946 that the British could not seek to re-establish their imperial state. British domestic and international opinion would not tolerate it, British worldwide military force was insufficient and British troops would anyway probably not fight in such a situation. 
Furthermore, the administrative machinery of the imperial state was just not strong enough to effect such a policy. ${ }^{17}$

The ending of British rule in August 1947 was in fact achieved by the British and Indian politicians working together despite Wavell's fears of total political and administrative breakdown. In part this was because the British still had sufficient political influence to help manage if not control events, and they were intent on leaving in as orderly fashion as possible with no humiliating public image of defeat or scuttle. This was the task Lord Mountbatten undertook as the last Viceroy, as he cajoled and wooed in equal measure the key Indian political actors in the blistering heat of the summer of 1947. They agreed on a transfer of power not to a single Indian nation but to two national states, India and Pakistan. It was an outcome probably none of those concerned had hoped for and certainly none liked in the form in which it was achieved. But it resolved the immediate problems of the British and the main political parties. The Indian case underlines the fact that partitions of territory are often the consequences of the breaking of states, particularly where those states have been overarching constructs incorporating multiple ethnic and religious groups, or territories with distinctive identities. Opposition movements to established states often cannot survive the reality of the impending end of the regime they have been fighting. A common enemy is a powerful glue to any opposition movement: but the prospect of freedom and the fruits of power often opens up pre-existing and deeply felt divisions.

The way in which the raj ended was also the result of the growth over at least the previous three decades of a political class who wished to inherit rather than destroy the imperial state. The politicians, who had alternated between non-cooperation and productive use of the powers afforded by the reformed legislatures, were poised to continue their political careers in the existing structures but without the British presence. Indian civilian servants of the raj, from those in the ICS down to the humble clerk in the district office, expected to keep their jobs, while the police and military were ready to work for an Indian state, particularly as their officer classes had been progressively Indianised by 1947. Also important in determining the nature of this imperial ending was the comparative absence of violence against those who represented the raj. Such violence there had been in 1942 during the so-called Quit India movement, in a few specific areas of northern India. But by 1946-7 there was no need for the politicians to launch violent or non-violent action as it was clear the British were going. Here of course the absence of an expatriate settler society greatly facilitated British policymaking in India and in Britain, as there were few British people

${ }^{17}$ Note by Attlee, undated but some time in mid Nov. 1946, Document No. 35 of Mansergh \& Moon (eds.) (1980). 
who considered India 'home' and wished to retain resources and political positions. ${ }^{18}$ In those areas where local and sporadic outbreaks of violence occurred, they were between different religious communities, in anticipation of independence or in retaliation for real or rumoured attacks on their own group. When violence did erupt with unexpected and destructive force in parts of northern India, most devastatingly in the Punjab, the British were already leaving, and it was the task of their successors to deal with it and with the human tragedies it created.

\section{REFASHIONING THE STATE}

I turn now to the remaking of states. We know from the evidence of contemporary and earlier waves of state-making in the aftermath of revolutions and civil wars that huge problems confront those who try to make new states out of the debris of conflict. Where do they turn for personnel-for people to become the police and military as well as civil servants? Where are the new political class and are they trained in the conventions of civil politics? How do they create new administrative structures? All this threatens to overwhelm one-time oppositions who find themselves in power, just at a time when civil society, as well as the infrastructure of normal life, may have been virtually destroyed, while the expectations of their followers are immense.

On the Indian subcontinent there was no revolution, and civil strife broke out in only limited places. Two successor states, India and Pakistan, emerged from the breaking of the British raj. But their trajectories could not have been more different. One struggled to survive and eventually broke apart in 1971. What remained as Pakistan was itself deeply divided by ethnic and regional conflicts, became increasingly dominated by the military and security services, and by the start of the 21 st century was mired in regional and international conflict, while itself in many respects a failing state. By contrast India weathered persistent economic crisis as a unified, stable nation state, developing a distinctive style of democratic politics, and emerged into the new century as a global power. There are many reasons for this difference in post-imperial state making. Among them were the sheer size, resources and geography of India compared to the much poorer and two-winged Pakistan of $1947 .{ }^{19}$ The ideological foundations of the two states were also significant. India had a secure image of what an Indian nation should look like, particularly under the guidance of Nehru, and with the image of the martyred Gandhi ever present in national imagery and discourse. It

\footnotetext{
${ }^{18}$ On the way British people in India inculcated the idea of Britain as 'home' into their children in India, and their retirements to Britain, see Buettner (2004).

${ }^{19}$ All the property of government was divided between the two states: Pakistan received $20 \%$ and India $80 \%$. For the tragic detail of this and other aspects of partition see Khan (2007).
} 
helped that Nehru and so many of his colleagues from the nationalist movement lived and worked at different levels of the political system for a decade or more after independence. (Nehru, for example, was prime minister, from 1947 until his death in 1964.) By contrast Pakistan had a much smaller established political elite from which to draw for leadership; and Jinnah died tragically soon after independence. But more deeply the ideology of 'Pakistan' was a very recent flowering, and even at the time of independence many of those who were to end up as Pakistani citizens had no idea of what it might mean in practical terms. Although the dominant trope in its national ideology was the safety of Muslims, this proved insufficient as a binding loyalty to the new state. As crucial was the fact that the Indian National Congress had never been the dominant political organisation in the areas which became Pakistan, but neither had any other comparable group. Groups and alliances built on very local foundations had tended to proliferate in these areas until very late in the process of imperial ending, when finally the Muslim League became the dominant party in what was to become Pakistan. By contrast in India Congress had spread its organisation throughout the rest of the subcontinent, and by the late 1930s had become the party of choice for anyone hoping for political influence. The result was a deeply rooted political system geared to winning local and national elections, as much as to organising opposition to the raj. Its strength lay in its social and ideological hospitality. Almost anyone with local influence was welcome into its ranks, and it deliberately made alliances with the dominant groups in each locality. So it became after independence what is often called an 'umbrella party'. It was well accustomed to working the political structures it had inherited from the old dispensation, and it was a powerful vehicle for the expression of local discontents and aspirations. ${ }^{20}$

Inheritance is probably the word which best describes the remaking of India after the raj. The new Constitution of 1950 which provided the political framework for the new republic drew heavily on the 1935 Government of India Act, drawing about 250 articles directly from it. There was consequently little change in the decision-making structures in Delhi or in the provinces, which now became states within the Indian Union. Civil government continued as before, not least because so much of it had been in the hands of Indians before 1947. Even that most imperial of institutions, the ICS, continued unchanged in all but name as Indians rose rapidly in its ranks, stepping into the shoes of their departing British colleagues. ${ }^{21}$ The military and police now answered to a national government; the major change there was the departure of many Muslims in the services to Pakistan. The Congress also continued its political role as the dominant party and now the party of government, much

\footnotetext{
${ }^{20}$ On this process see Weiner (1967).

${ }^{21}$ On the continuity between the ICS and its successor, the Indian Administrative Service, see Potter (1986).
} 
as it had done for the brief years 1937-9 when it had entered into cooperation with the imperial state.

Inheritance, continuity and a relatively peaceful transfer of power to the new India certainly made for stability. But there were dangers inherent in not having radically to create a new state. Nehru was to discover this painfully as he began to realise that the state's structures could not deliver the policies of change for which he and many others had hoped..$^{22}$ An essentially imperial state could not be bent to provide swiftly the social and economic goods to which the people rightly aspired in a nation state they could now call their own. Economic development, radical social reform in the areas of caste and gender, greater socio-economic equality, mass education and health care-all these were changes he and the majority hoped for but the state failed to achieve, despite the effort poured into a series of Five Year Plans intended to take India towards such goals. For much of his premiership the country could not even feed itself without foreign aid, as predominantly subsistence agriculture could not sustain a growing population. The case of land reform is instructive: it was stymied, partly by the political opposition of the dominant landed groups who had infiltrated Congress, and partly by the weakness of an administrative structure designed to provide light government and efficient tax collection. Moreover, the continuity of personnel within the civil service meant a continuity of administrative culture, particularly a paternalism which was unresponsive to popular wishes, and driven primarily by the desire for stability and order. Continuity in the broader political system and the sorts of people who pursued power within it, also helped to establish Indian democracy on firm social foundations. But again there was a cost - the hold of the socially dominant in each area on the legislatures and on the internal working of the Congress. Those who bore the cost were at the base of society and the less powerful. It was little wonder that eventually social and political commentators would talk of an internal imperialism in India, despite the external structures of a nation state and of a functioning democracy. The Indian nationalist movement had played a key role in ending the British raj. It had not broken, and indeed had never intended to break, the state created by the British.

$* * *$

For many decades the state dominated the world and work of professional historians. In the later 20th century scholarly attention to the state and the actions of those seeking to control the state was often replaced by other historiographical emphases, including, for example, an entirely proper interest in the experience of those who leave few of the historical records generated by the state. The professional practice of

\footnotetext{
${ }^{22}$ See Brown (2003), particularly Part 5.
} 
history like many other subjects in the arts and humanities was also affected by the so-called 'cultural turn'. Most recently the significance of broader geographical regions, such as the Atlantic and Indian Ocean worlds, has been studied within the conceptual framework of global history. These disciplinary developments have proved immensely fruitful in the study of the South Asian subcontinent and elsewhere. Giving voices to those who seldom contributed directly to the colonial state archives generated the flowering of scholarship known as the Subaltern Studies movement for example, and to the developing interest in women's experience in India, and more broadly in the issue of gender in the practice and experience of imperialism. ${ }^{23}$ However, contemporary events, as well as those seismic changes in state formations still within living memory, should remind us that struggles to control or break states are still powerful and often bitter. Where these are prolonged they can lead to regional as well as domestic instability, with profound international consequences. The failure of states can be equally dangerous and destabilising. This was the thinking behind the mini series of British Academy lectures on the making and breaking of states, of which this was one. The experiences of men and women on the South Asian subcontinent in the mid-20th century point us to significant issues as we revisit problems of state structures and opposition to them, and try to understand the dynamics of these great political upheavals.

\section{REFERENCES}

Ansari, Sarah F.D. (1992), Sufi Saints and State Power. The Pirs of Sind, 1843-1947 (Cambridge, Cambridge University Press). http://dx.doi.org/10.1017/CBO9780511563201

Brown, Judith M. (1972, digital reprint 2007), Gandhi's Rise to Power. Indian Politics 1915-1922 (Cambridge, Cambridge University Press).

Brown, Judith M. (1977, digital reprint, 2008), Gandhi and Civil Disobedience. The Mahatma in Indian Politics 1928-34 (Cambridge, Cambridge University Press).

Brown, Judith M. (2003), Nehru. A Political Life (New Haven \& London, Yale University Press).

Brown, Judith M. (ed.) (2008), Mahatma Gandhi. The Essential Writings, new edn (Oxford, Oxford University Press).

\footnotetext{
${ }^{23}$ The widening of the historiographical interests of historians working on the British Empire more broadly has been mirrored in writing on the subcontinent in particular. A good introduction to shifts in imperial historiography is Winks (ed.) (1999). See also O'Hanlon, 'Gender in the British Empire', chap. 16 of Brown \& Louis (eds.) (1999). It is significant that in the Companion Series to The Oxford History of the British Empire there is a volume on gender, Levine (ed.) (2004). On shifts in Indian historiography see, for example, the 'Subaltern Studies' Series which began publication in 1982: a selection can be found in Guha \& Spivak (eds.) (1988). The growing attention to issues relating to women is seen in the landmark volume in The New Cambridge History of India series, Forbes (1996). O'Hanlon's chapter cited above in this footnote also notes major developments in interest in gender in the historiography of the subcontinent, mainly from the 1990s onwards.
} 
Buettner, E. (2004), Empire Families, Britons and Late Imperial India (Oxford \& New York, Oxford University Press).

Forbes, G. (1996), Women in India (Cambridge, Cambridge University Press). http://dx.doi.org/10.1017/CHOL9780521268127

Gopal S. (ed.) (1985), Selected Works of Jawaharlal Nehru Second Series, Vol. 3 (New Delhi, J. Nehru Memorial Trust).

Guha, R. \& Spivak, G.C. (eds) (1988), Selected Subaltern Studies (New York \& Oxford, Oxford University Press).

Khan, Y. (2007), The Great Partition. The Making of India and Pakistan (New Haven \& London, Yale University Press).

Kudaisya, K. (2006), Region, Nation, 'Heartland'. Uttar Pradesh in India's Body Politic (New Delhi, Sage Publications).

Levine, P. (ed.) (2004), Gender and Empire (Oxford, Oxford University Press).

Mansergh, N. \& Moon P. (eds.) (1980), Constitutional Relations Between Britain and India. The Transfer of Power 1942-7, vol. IX (London, HMSO).

Moon, P. (ed.) (1973), Wavell The Viceroy's Journal (London, Oxford University Press).

Nehru, J. (1936), An Autobiography (London, John Lane).

O'Hanlon, R. (1999), 'Gender in the British Empire', chap. 16 of J.M. Brown \& Wm. R. Louis (eds.) (1999), The Oxford History of the British Empire. Volume IV. The Twentieth Century (Oxford \& New York, Oxford University Press).

Parel, A.J. (ed.) (1997), Gandhi. Hind Swaraj and other writings (Cambridge, Cambridge University Press).

Potter, D. (1986), India's Political Administrators 1919-1983 (Oxford, Clarendon Press).

Reeves, P. (1991), Landlords and Governments in Uttar Pradesh. A study of their relations until zamindari abolition ( Bombay, Oxford University Press).

UK Government (1930), Indian Statutory Commission Volume 1. Report of the Indian Statutory Commission Volume 1-Survey, CMD 3568 (London, HMSO).

Weiner, M. (1967), Party Building in a New Nation. The Indian National Congress (Chicago, Chicago University Press).

Winks, R. (ed.) (1999), The Oxford History of the British Empire. Volume V. Historiography (Oxford, Oxford University Press).

The author: Professor Judith M. Brown is Emeritus Beit Professor of Commonwealth History in the University of Oxford and Emeritus Professorial Fellow of Balliol College. She has written widely on imperial history, modern Indian politics and history, and the history of the South Asian diaspora. She is a Member of the European Academy.

Contact: Balliol College, Oxford OX1 3BJ

This article is licensed under a

Creative Commons Attribution-NonCommercial-NoDerivs 3.0 Unported License.

Journal of the British Academy (ISSN 2052-7217) is published by

The British Academy - the national academy for the humanities and social sciences.

10-11 Carlton House Terrace, London, SW1Y 5AH

www.britac.ac.uk 